\title{
COMPUTER DATA PROTECTION LAWS AN IMPORTANT RECENT STUDY
}

COMPUTER Networks is the official journal of the International Council for Computer Communications. Beginning publication in 1977. it is now in its fourth volume. The present editor-in-chief is Philip $H$. Enslow, Jr. of the School of Information and Computer Science, Georgia Institute of Technology in Atlanta, Georgia, U.S.A. North-Holland Publishing Company, P.O. Box 103, 1000 AC Amsterdam, The Netherlands, is the publisher. Each annual volume consists of six 80-100 page long issues. The annual subscriptions for libraries and other institutions are U.S. $\$ 56.00$ or Df. 115.00 ; personal subscriptions are U.S. $\$ 29.25$ or Dfl. 60.00 a year.

As a rule we would not bring a journal of this nature to the attention of law librarians because its relevance to law and other law-related subjects is marginal at best. However, one recent issue of CoMPUTER Networks happens to be an exception. Lawyers and law librarians may find more than a passing interest in its content.

Issue no. 3 of volume 3 (June 1979) is dedicated entirely to "Computer Networks and Data Protection Law". Edited by Frits Hondius, a foremost European expert on questions relating to the legal aspects of computerization and the author of Emerging Data Protection in Europe, and Paul Sieghart, the leading authority on data protection law in Britain, this issue includes the following articles:

"Data Protection and Law Reform", by M.D. Kirby, the first chairman of the Australian Law Reform Commission and a member of the Australian judiciary;

"Privacy in the Future Information Society", by Yoneji Masuda, president of the Institute for Information Society and a senior executive of the Japan Computer Usage Development Institute;

"Computers and the International Flow of Information", by Carole Parsons, a former executive director of the U.S. Privacy Protection Study Commission;

"Survey of National Data Protection Legislation", by Godfrey Stadlen, who has worked on the staff of the United Kingdom Data Protection Committee;

"Legal Problems of Computer Networks: A Methodological Survey", by Professor Wilhelm Steinmüller, Faculty of Law at the University of Regensburg in the Federal Republic of Germany;

"Legal Aspects of Data Flows Between Public Agencies in France", by Professor Herbert Maisl, Faculty of Law and Economics at the University of Orleans in France; 
"Problems of Data Protection Law for Private Multinational Communication Networks", by Peter L.P. Rooms and John Dexter, computer consultants; and

"Towards a European Convention on Data Protection", by H. Golsong, Director of Human Rights of the Council of Europe in Strasbourg, France.

This important study of computer data protection law should not be overlooked by lawyers.

\section{THE GREAT LEGAL AUTHORS OF THE PAST HEINECCIUS (1681-1741)}

Johann Gottlieb Heineccius was one of the most famous jurisconsults ever produced by Germany. Born in Eisenberg in 1681, he studied theology at Leipzig and law at Halle. For a brief period he was a professor at the University of Franeker, but returned to Frankurt Am Oder in 1727 at the request of the king of Prussia. In 1733 he returned to Halle, where he died on August 31, 1741.

Undoubtedly the quality of his works is due to his constant labor in treating law as a rational science. Through his works one is struck by the continual referral to first principles and the integrated system of legal philosophy he developed.

One of his most famous works is Elementa juris naturae et gentium, originally published in 1738 (published in English translation by Turnbull in 1741, 1751 and again in 1763 in London under the title $A$ Methodical System of Universal Law).

Other famous works include:

Historia juris civilis Romani ac Germanici, Halle, 1733, Leyden 1740, with additions 1748 .

Elementa juris civilis secundum ordinem Institutionem, Franeker, 1725 ; Strasbourg, 1727, and numerous reprints.

Elementa juris civilis secondum ordinem pandectarum, Numerous editions, the best of which are Frankfurt, 1756 and Utrecht, 1772. The Louvain reprint of 1778 is annotated in order to reconcile the author's views with those of the Catholic Church.

Opera ad universam jurisprudentiam, philosophiam et litteras humaniores pertinentia, Geneva, 1744-48. Eight volumes in quarto. Reprinted in Geneva, with additions 1771, nine volumes in quarto. 